\title{
A Morphological and Histological Investigation of the Sinus Interdigitalis in Konya Merino Sheep
}

\author{
Zekeriya Özüdoğru1,a, Ramazan İlgün ${ }^{1, b, *}$, Derviş Özdemir ${ }^{2, c}$ \\ ${ }^{1}$ Department of Anatomy, Faculty of Veterinary Medicine, Aksaray University, 68100 Aksaray, Turkey \\ ${ }^{2}$ Department of Anatomy, Faculty of Veterinary Medicine, Atatürk University, 25240 Erzurum, Turkey
}

*Corresponding author

\begin{tabular}{|c|c|}
\hline A R T I C L E I N F O & A B S T R A C T \\
\hline $\begin{array}{l}\text { Keywords: } \\
\text { Konya merino sheep } \\
\text { Histology } \\
\text { Morphology }\end{array}$ & $\begin{array}{l}\text { In the study, it was aimed to reveal the morphological, morphometric and histological } \\
\text { characteristics of sinus interdigitalis found in the fore and hind feet of Konya merino sheep. For this } \\
\text { purpose, the fore and hind feet of } 10 \text { Konya merino sheep, weighing between } 44-79 \mathrm{~kg} \text {, were used. } \\
\text { Sinus interdigitalis were dissected out from the feet, and after morphometric measurements were } \\
\text { made, morphological examinations were performed and photographed. The shape of the sinus } \\
\text { interdigitalis, present in all the forefeet and hind feet, resembled a pipe consisting of neck and body. } \\
\text { It was determined that the neck part was longer than the body at all feet. The inner surface of the } \\
\text { gland was covered with hair, and there was more hair on the neck than on the body. The weight of } \\
\text { the gland, body length and diameter, flexura, canal length and diameter were measured } \\
\text { morphometrically. In the measurements made, it was determined that all the values of the forefeet } \\
\text { were higher than the hind feet. In histological examination, it was found that the wall of the sinus } \\
\text { interdigitalis consists of three layers: epidermis, dermis and fibrous capsule, and in the dermis, hair } \\
\text { follicles, sebaceous glands, m. arrector pili and sweat glands were found. }\end{array}$ \\
\hline
\end{tabular}

Morphology

Sinus interdigital

Sweat glands

\section{Introduction}

The breeding of Merino sheep in Anatolia started in 1933. Harmonization with the region has been ensured by crossbreeding with various sheep breeds found in Anatolia. The fleece of Merino sheep, which is always on the agenda with its fleece yield and quality wool, is still used in weaving (Akçapınar, 1994). Konya merino sheep was obtained from the combination of G2 and G3 level German meat merino with Akkaraman cross-breed sheep and rams. They carry around $90 \%$ merino genes. The body is completely white, the sheep and rams are hornless, the tail is thin and long (Anonim, 2021). The skin shapes formations with different functions in some parts of the body (Pourlis, 2010). One of these formations is the sinus interdigitalis formed between the fingers in sheep (Taşbaş, 1985; Dursun,2000). It has been reported that the sinus interdigitalis is formed as a result of the invagination of the ectoderm layer towards the mesoderma embryologically (Sivachelvan et al.,1992). Sinus interdigitalis are specialized skin structures that contain all layers of the skin and contain sebaceous glands and sweat glands in the apocrine character. It has been reported that their secretions contribute to the elasticity of the skin in the region where they are located, they play a role in protection from ultraviolet rays (Abbasi et al., 2009) and in the sheep watching each other (8). Sinus interdigitalis, also called sinus biflex, is a gland located on both sides of the midline of the feet between the toes, on the anterior side of the feet (Çalışlar, 1970). It resembles a pipe with a narrow and long neck and a blind pouch (Aslan et al., 2010). One of the most common feet diseases in sheep is inflammation of the sinus biflex (8.11). In relation to this disease, Meliha and Sarıtaş, (2014) diagnosed with 15.88 in the animals examined in Afyon region, $3.67 \%$ of the sick animals in their study in Yurdakul Sivas region (Sağlayan, 2003), and $25.3 \%$ in animals at the end of the penile period in the study conducted in Konya (İzci et al., 1994). Although there are some studies on sinus interdigitalis in sheep (Avdic et al., 2013; Award et al., 2015), there is no study on this subject 
in Konya merino sheep, which is widely grown in Central Anatolia. This study will contribute to the elimination of deficiencies in the anatomical structure, location and morphometry of sinus interdigitalis in Konya merino sheep.

\section{Material and Method}

Forefeet and hind feet of 10 Konya merino sheep, weighing between 44-79 $\mathrm{kg}$, slaughtered in a slaughterhouse were used in the study. Sinus interdigitalis were dissected out from the feet, and after morphometric measurements were made, morphological examinations were performed and photographed. Morphometrically, gland weight, body length and diameter, flexura, ductus length and diameter were measured. Mitutoyo brand digital caliper was used for measurement. For ethics report, Dead animal or its tissue, slaughterhouse materials, waste fetuses are not subject to the permission of HADYEK due to paragraph 2 of article $(\mathrm{k})$ of the regulation regarding the working procedures and principles of animal experiments ethics committees.

\section{Histological Analysis}

After morphological and morphometric examinations, it was fixed in $10 \%$ formaldehyde solution. After washing the tissues, they were subjected to dehydration and alcohol series and embedded in paraffin blocks. Subsequently, Crossman-modified Mallory triple staining was performed by taking 5-7 $\mu$ sections and examined histologically under a light microscope (Nikon Eclipse i50, Tokyo, Japan).

\section{Statistical Analysis}

Statistical analyzes were performed using SPSS version 22. T-TEST PAIRS procedure was used for the analysis of the data obtained from the anterior and posterior and right and left feet. All data are presented as mean \pm standard deviation values. Statistical differences were considered significant at $\mathrm{P}<0.05$.

\section{Results}

The shape of the sinus interdigitalis, present in all the fore and hind feet, resembled a tobacco pipe consisting of neck and body. It was determined that the neck part was longer than the body at all feet. (Figure 1,2). The inner surface of the gland was covered with hair, and there was more hair on the neck than on the body (Figure 3). It was determined that the body part of the gland was located at the level of corium limitans and the neck part connected to the body went in the proximo-dorsal direction and opened out through a hole in the dorsal part of the articulatio interphalangia proximalis (Figure 4, 5).

In the morphometric measurements, it was determined that all the values of the forefeet were higher than the hind feet. Accordingly, it was determined that the weight of the glands in the forefeet and hind feet was statistically very important, the values between the canal diameter and the body length and diameter were significant, and the ductus length was insignificant (Table $1 ; \mathrm{P}<0.05$ ). There was no statistically significant difference in the evaluations between the right and left feet (Table 2; $\mathrm{P}<0.05$ ).

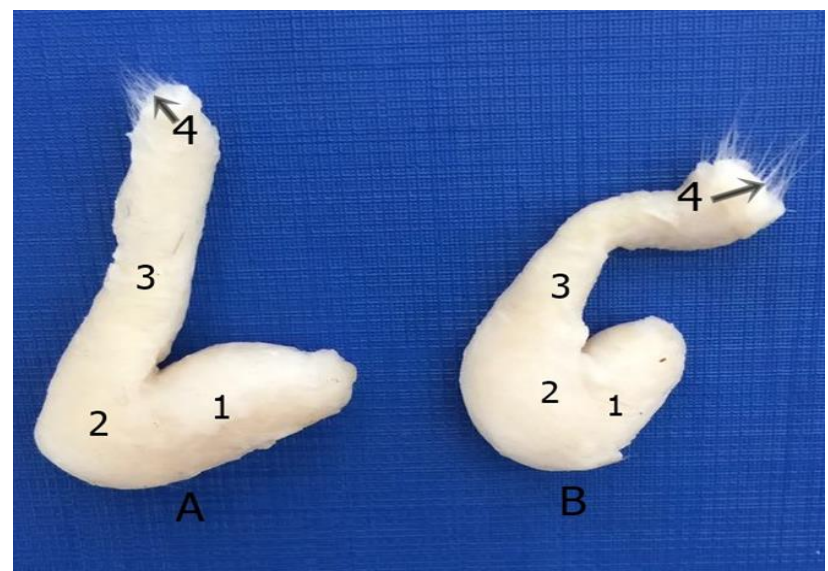

Figure 1. View of the sinus interdigitalis of the right fore (A) and right hind feet (B).

1. Body, 2. Flexura, 3. Ductus, 4. Orificium externa of sinus interdigitalis.

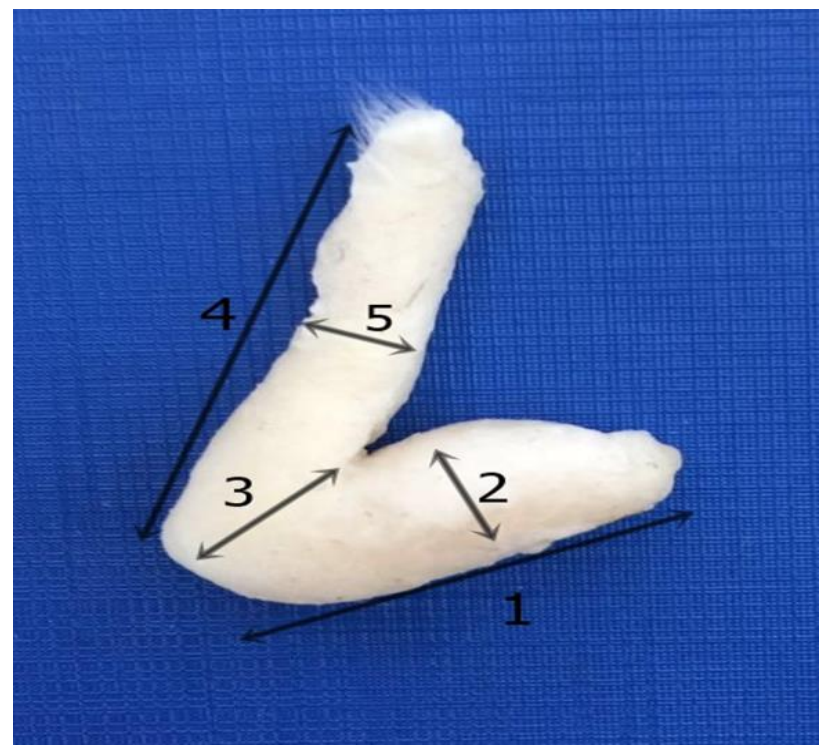

Figure 2. Morphometric measurements of the sinus interdigitalis on the right forefoot

1. Body length, 2. Body width (diameter) 3 . Flexura length, 4. Ductus length, 5. Ductus width (diameter).

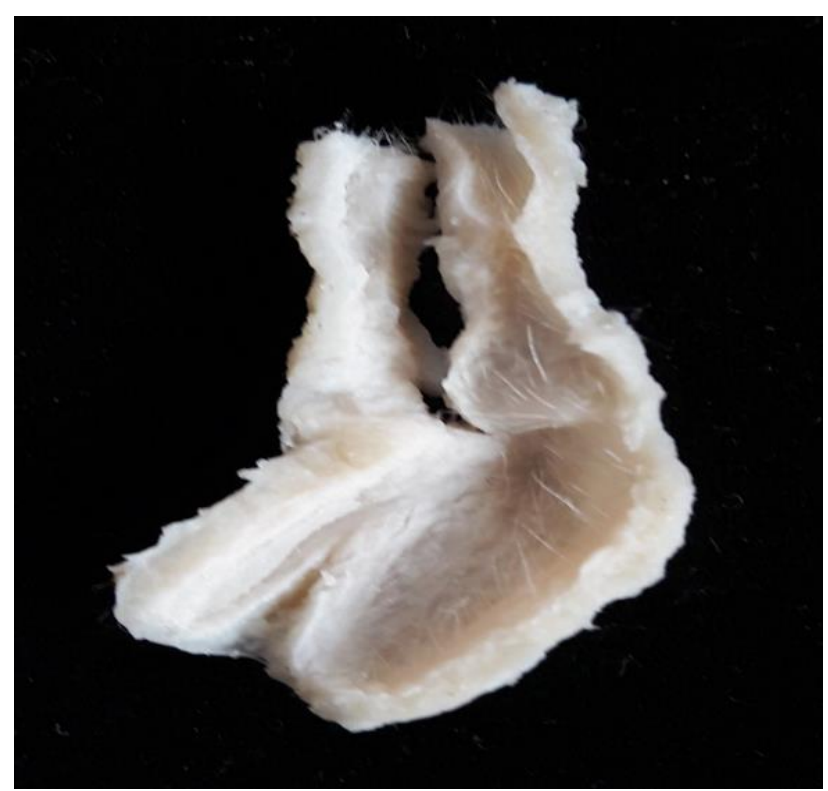

Figure 3. Sagittal section view of sinus interdigitalis 


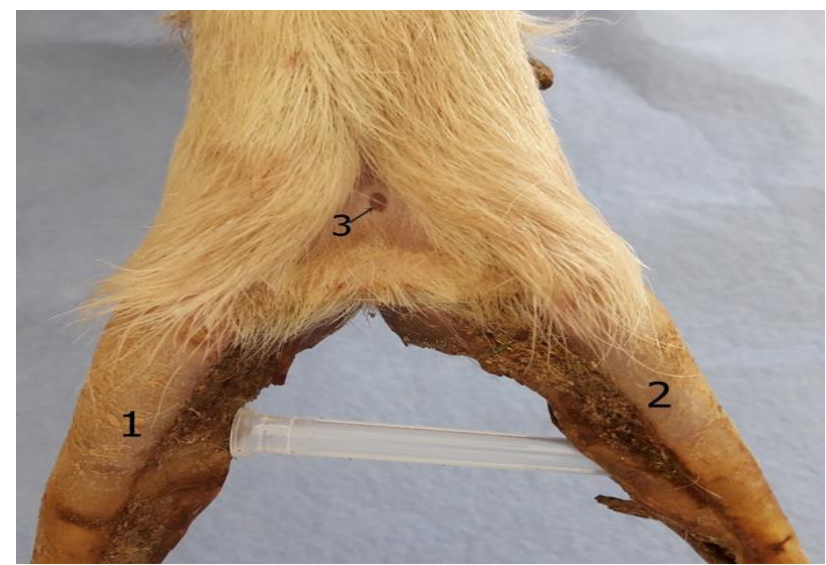

Figure 4. Dorsal view of the right fore foot.

1. Phalanx distalis (capsula ungula, lateral), 2. Phalanx distalis (capsula ungula, medial), 3. orificium externa of sinus interdigitalis.

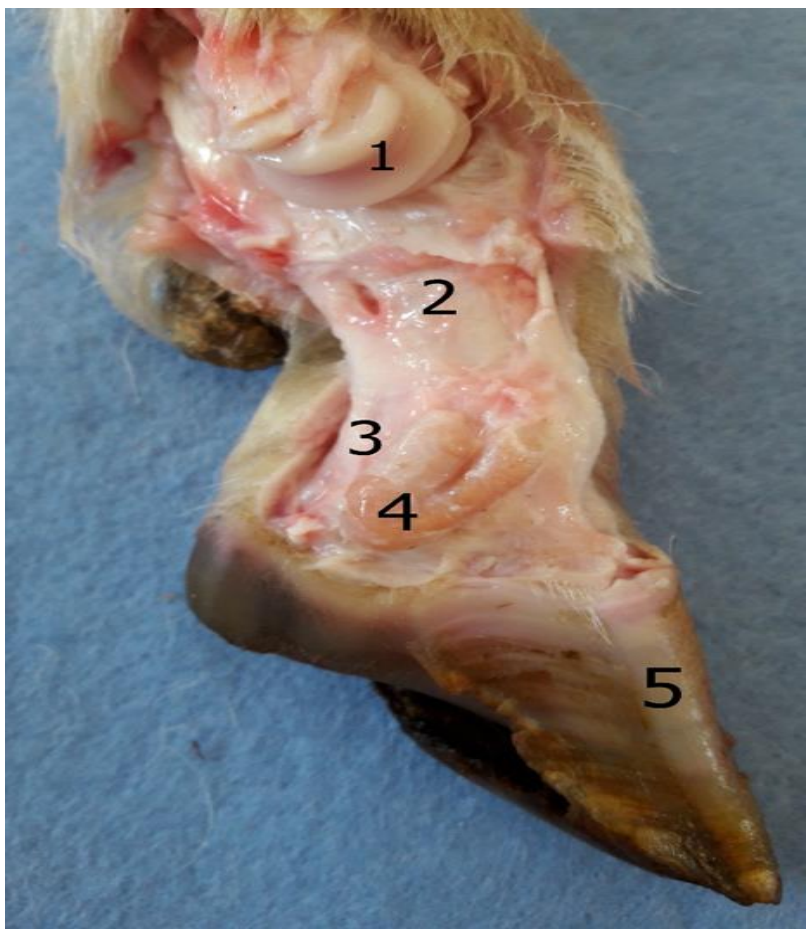

Figure 5. The medial view of the forefoot and the placement of the sinus interdigitalis

1. Caput metacarpi, 2. Phalanx proximalis, 3. Phalanx media, 4. Sinus interdigitalis, 5. Phalanx distalis (capsula ungula, facies axialis).

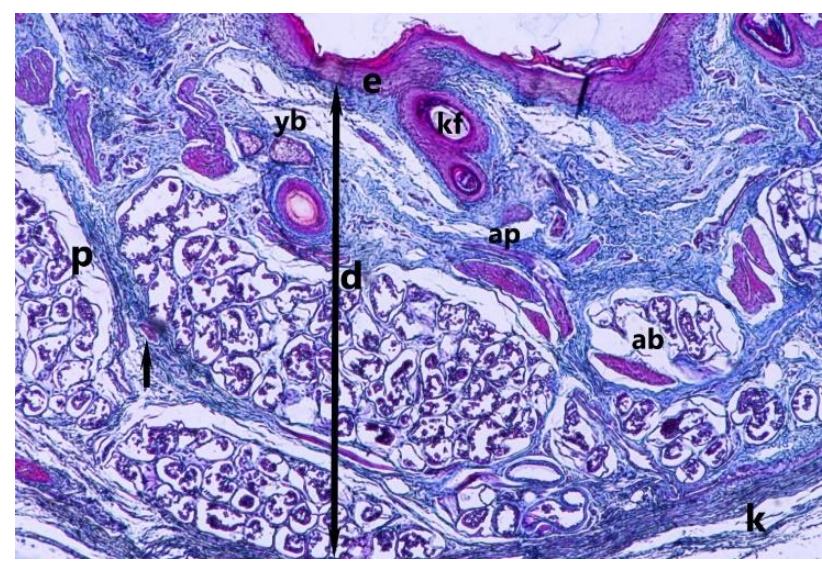

Figure 6: A transversal section of the sinus interdigitalis.

Stratified squamous keratinized epithelium (e), dermis (d), fibrous capsule (k), sebaceous gland (yb), sweat gland (arrow), m. arrector pili (ap), hair follicle (kf), apocrine gland (ab), parenchyma (p). Crossman's Modified Triple Painting. Bar: $100 \mu \mathrm{m}$.

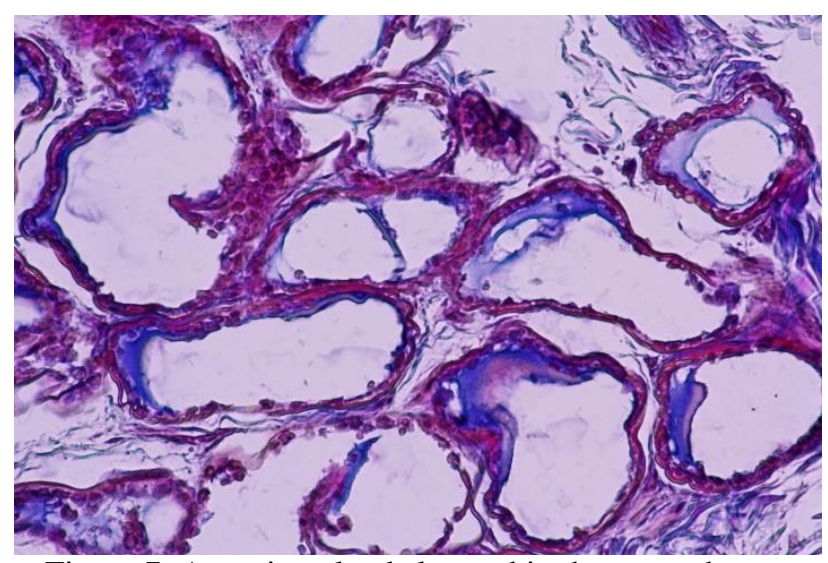

Figure 7: Apocrine glands located in the parenchyma.

Crossman's Modified Triple Painting. Bar: $20 \mu \mathrm{m}$.

In the histological examination of sections of Konya merino sheep, it was seen that the sinus interdigitalis wall was composed of three layers from the lumen: epidermis, dermis and fibrous capsule. The epidermis, the layer closest to the lumen, consisted of a stratified squamous keratinized epithelium. Dermis, it consisted of different structures such as sebaceous glands, hair follicles, $\mathrm{m}$. arrector pili and sweat glands. Each hair follicle of different sizes was surrounded by connective tissue areas and located close to the hair follicles. The $\mathrm{m}$. arrector pili could be easily selected. In the sebaceous glands arranged in the form of acinus clusters, it was determined that the acinus consisted of cells of different sizes. The fibrous capsule surrounding the sinus interdigitalis wall outermost was composed of collagen fiber bundles that were parallel to each other (Figure 6). Areas surrounded by a single-layered cubic epithelium belonging to apocrine-secreting glands, which are located in the lower parts of the dermis and constitute the parenchyma of the sinus interdigitalis, were also clearly visible (Figure 7).

\section{Discussion}

In the study, it was determined that sinus interdigitalis is present in both forefeet and hind feet, resembles a tobacco pipe consisting of neck and body, and the neck part is longer than the body, as reported in the literature (Award et al., 2015; Gürbüz et al., 2017). While Calislar (1970) reported that there was no sinus interdigitalis in the feet of bristle goats and Ankara goats, some other authors (Karahan et al. (2007) and Bahadır and Yakışık (1988) reported that this gland was rudimentary in goats. Janicki et al. (2003) they observed that the sinus interdigitalis was found only on the hind feet of the roe deer and not on the forefeet.

In Hasak (Kara et al., 2020) sheep, the interdigital gland weights of the forefeet and hind feet were 1.05 and 0.56 , Hasmer (Kara et al., 2020) 1 and 0.6, 1.88 and 0.95 in Hemshin (Gürbüz et al., 2017), and 1.25 and 0.81 in Awassi sheep (Y1lmaz et al., 2017), respectively. It was determined as $1.13 \pm 0.12$ and $0.62 \pm 0.05$ in Konya merino sheep. According to this information, the weight of the sinus interdigitalis of Konya merino sheep is higher than the Hasak and Hasmer sheep and lower than the Hemshin and Awassi sheep. 
Table 1. Morphometric values (Arithmetic mean \pm Standard deviation $/ \mathrm{mm}$ ) of sinus interdigitalis of forefeet and hind feet in Konya Merinos sheep; $\mathrm{P}<0.05$

\begin{tabular}{l|ccc}
\hline \multicolumn{1}{c|}{ Parameters } & Forefeet & Hind feet & P \\
\hline Weight & $1.126 \pm 0.12$ & $0.62 \pm 0.05$ & 0.002 \\
Body length & $18.78 \pm 0.49$ & $13.57 \pm 0.37$ & 0.018 \\
Body width & $6.97 \pm 0.45$ & $5.67 \pm 0.29$ & 0.049 \\
Flexura & $6.91 \pm 0.38$ & $5.78 \pm 0.31$ & 0.105 \\
Ductus length & $26.65 \pm 0.73$ & $24.67 \pm 0.98$ & 0.123 \\
Ductus width & $3.76 \pm 0.25$ & $3.36 \pm 0.17$ & 0.020 \\
\hline
\end{tabular}

Table 2. Morphometric values of sinus interdigitalis of the right and left forefeet and hindfeet (Arithmetic mean \pm Standard deviation / mm) in Konya Merinos sheep; $\mathrm{P}<0.05$

\begin{tabular}{l|cccccc}
\hline \multicolumn{1}{c|}{ Parameters } & Weight $(\mathrm{g})$ & Body length $(\mathrm{mm})$ & Body width (Diameter) & Flexura & Ductus length & Ductus width \\
\hline Forefeet (Right) & $1.124 \pm 0.15$ & $19.00 \pm 0.98$ & $6.85 \pm 0.50$ & $7.05 \pm 0.35$ & $26.17 \pm 0.53$ & $3.78 \pm 0.28$ \\
Forefeet (Left) & $1.128 \pm 0.13$ & $18.55 \pm 1.24$ & $7.08 \pm 0.42$ & $6.77 \pm 0.52$ & $27.12 \pm 1.13$ & $3.74 \pm 0.28$ \\
\hline \multicolumn{7}{c}{} \\
\hline
\end{tabular}

As reported in the literature (Gürbüz et al., 2017; Y1lmaz et al., 2017; Kara et al., 2020), it was found that the gland in the forefeet was heavier and larger in size than the gland in the hind feet. Uğurlu (1991), reported that there was no difference in the size and shape of the sinus interdigitalis in the fore and hind feet of sheep.

In the study, it was determined that the channel length $(26.65 \pm 0.73)$ and diameter $(3.76 \pm 0.25)$ of the sinus interdigitalis in the forefeet of Konya merino sheep are greater than the canal length $(24.67 \pm 0.98)$ and diameter (3, $36 \pm 0.17$ ) of the hind feet.

According to this finding, Hasak (Kara et al., 2020) (29.65 and 3.60; 23.51 and 2.91), Hasmer (Kara et al., 2020) (26.39 and 3.77; 22.64 and 3.27), Hemshin (Gürbüz et al., 2017) (20.90 and 4.60; 18.95 and $3.05 \mathrm{~mm}$ ) and Iran Bakhtiari sheep (Behzad Mobini and Adermanabadi ,2017) (3.50 and $17.7 ; 2.88 \times 15.5)$, but it does not match the data on the forefeet (25.03 and 2.01) and hind feet (27.23 and 2.05) of the Kivircik sheep (Demiraslan et al., 2014). The body length and diameter of the sinus interdigitalis in the forefeet and hind feet, respectively, Hasak (Kara et al., 2020) 16.33 and 6.73; 12.89 and 5.24, Hasmer (Kara et al., 2020) 17.25 and 7.15; It was reported that the mean values of the forefeet and hind feet were 13.67 and 5.59, and 17.42 and 8.12 in the Awassi sheep (Yilmaz et al., 2017). In this study, the body length and diameter of the sinus interdigitalis in the forefeet and hind feet of Konya merino sheep were found to be $18.78 \pm 0.49$, respectively; $6.97 \pm 0.45$ and $13.57 \pm 0.37$; It was determined to be $5.67 \pm 0.29$. In accordance with the data of the literature (Behzad Mobini and Adermanabadi, 2017; Kara et al., 2020) of our finding of this situation, it is concluded that the body length and diameter of the forefeet are greater than the hind feet. However, Demiraslan et al. (2014) reported that the body diameter of the sinus interdigitalis of the hind feet is larger than that of the forefeet in Kivircik sheep, whereas Uğurlu (1991) reports that there is no significant morphological difference between the sinus interdigitalis in the forefeet and hind feet.
Histological investigations revealed that the wall of the sinus interdigitalis in Konya merino sheep such as Tuj (Aslan et al., 2010), Akkaraman (Karahan et al., 2007), Kıvırcık sheep (Süzer et al., 2016), Barbados black belly (Mohamed and Adogwa, 2016) and Egyptian (Awaad et al., 2015) and Iran's native sheep (Abbasi et al., 2009) it was observed that it consisted of three layers as dermis and fibrous capsule. Janicki et al. (2003) reported that there is no connective tissue in the interdigital gland, unlike our findings in roe deer.

In the dermis layer of the sinus interdigitalis, similar to the literature (Süzer et al., 2016; Mohamed and Adogwa, 2016), hair follicles, sebaceous and sweat glands, it had an m. arrector pili. Aslan et al. (2010) reported that lymph nodes were found in the dermis layer in addition to these formations in tuj sheep, but lymph nodes were not found in this study.

As a result; Although the morphometric and histological features of sinus interdigitalis in Konya merino sheep are mostly similar to other sheep breeds, it is thought that the differences in some parameters are due to environmental conditions and feeding patterns.

\section{Conflict of Interest}

The authors declare that there is no conflict of interest.

\section{References}

Abbasi M, Gharzi A, Mohammadzadeh S, Karimi H. 2009. Morphology and histology of the interdigital gland in an Iranian native breed of sheep. Journal of Animal and Veterinary Advances 8(6): 1157-1161.

Akçapınar H. 1994. Koyun Yetiştiriciliği. 8-14, Medisan Yayınevi, Ankara.

Anonim 2021. Hayvan besleme, http://hayvanbilgisi.com/koyun yetiştiriciliği/merinos koyunu-383, [Erişim tarihi:25 Mart 2021].

Aslan K, Kürtül I, Nazlı M, Ateş S. 2010. Morphologic features of the interdigital sinus of the Tuj sheep. Kafkas Üniversitesi Veteriner Fakültesi Dergisi 16: 623-626. 
Avdic R, Katica A, Malco N, Softic A, Tandir F, Cengic B, Bejdic P, Cutahija V, Hadziomerovic N. 2013. Morphological characteristics of interdigital diverticulum (sinus cutaneous interdigitalis) of Dubska Pramenka. Biotehnologija u stocarstvu 29(3): 441-448.

Awaad AS, Tawfiek MG, Moawad UK, Abdel Razek AH, Abedellaah BA, 2015. Morphohistological and surgical anatomy of the sinus interdigitalis in Egyptian native breeds of sheep. Beni-Suef University Journal Basic Applied Science 4(2): 157-166.

Bahadır A, Yakışık M. 1988. Yerli kıl keçisinde sinus interdigitalis' in morfolojisi. Uludag Üniversitesi Veteriner Fakültesi Dergisi 7: 87-92.

Behzad Mobini B, Adermanabadi VR. 2017. Effect of sex on histological and histochemical structures of interdigital sinus in adult Bakhtiari sheep of Iran. Iranian Journal of Veterinary Science and Technology 9(1): 33-38.

Çalışlar T, 1970. Sinus interdigitalisin morfolojik özellikleri. Ankara Üniversitesi Veteriner Fakültesi Dergisi 37-41.

Demiraslan Y, Akbulut Y, Deprem T, Karadağ Sari E, Aslan K. 2014. Morphological and morphometrical characteristics of the interdigital gland in Kivircik sheep. Turkish Journal of Veterinary and Animal Sciences 38: 1-5.

Dursun N. 2000. Veteriner Anatomi III. 197-198, Medisan Yayınevi, Ankara,

Gürbüz I, Demiraslan Y, Sarı EK, Aslan K. 2017. Morphologic and morphometric structure and arterial vascularization of glandula interdigitalis in male hemshin sheep. Kafkas Üniversitesi Veteriner Fakültesi Dergisi 23: 241-246.

İzci C, Koç Y, Avki S, Kul S. 1994. Konya bölgesi koyunlarında görülen ekstremite ve ayak hastalıklarının klinik ve radyolojik olarak değerlendirilmesi. Veteriner bilimleri dergisi 10(1-2): 16-21

Janicki Z, Hraste A, Slavica A, Konjeviæ D, Marinoviæ Z, Stubièan D. 2003. Morphohistological characteristics of the interdigital gland in the roe buck (Capreolus capreolus L. Veterinarski Arhiv 73: 27-38.
Kara H, Gedikli S, Özüdogru Z, Özdemir D, Balkaya H. 2020. A morphological, morphometrical and histological investigation of the interdigital gland in Hasmer and Hasak sheep. Folia Morphologica 79(4): 742-747.

Karahan S, Yildiz D, Bolat D. 2007. Scanning electron microscopic features of the ovine interdigital sinus. Acta Veterinaria Hungarica 55(4): 417-424.

Meliha İN, Sarıtaş ZK. 2014. Afyon bölgesi koyunlarında ayak hastalıkları prevalansının araştırılması. Kocatepe Vet Journal 7: $17-25$

Mohamed R, Adogwa A. 2016. Gross and Microscopic Features of the Interdigital Sinus in the Barbados Black Belly Sheep in Trinidad. International Journal of Research in Medical Sciences 2(7): 22-27.

Pourlis AF. 2010. Functional morphological characteristics of the interdigital sinus in the sheep. Folia Morphologica 69: 107-11.

Sağlayan A. 2003. Elâzı̆̆ bölgesi koyunlarında görülen ayak hastalıklarının klinik olarak değerlendirilmesi. Fırat Üniversitesi Sağlık Bilimleri Dergisi 17(1): 39-44

Sivachelvan MN, Yahaya A, and Chibuzo GA. 1992. Developmental changes in the interdigital pouch of Yankasa sheep. Small Rum. Research 9: 303-312.

Süzer B, Özgüden Akkoç CG, Arıcan İ, Yıldız H. 2016. Morphological and immunohistochemical features of interdigital sinus in Kivircik sheep. Kafkas Universitesi Veteriner Fakültesi Dergisi 22: 69-73.

Taşbaş M. 1985. Komparatif Veteriner Anatomi, Duyu Bilimi. Ankara Üniversitesi Veteriner Fakültesi Yayınları 89-90.

Uğurlu S. 1991. Koyunlarda sinus interdigitalislerin 1 şık mikroskobik yapısı üzerine incelemeler. İstanbul Üniversitesi Veteriner Fakültesi Dergisi 17(1): 1-7.

Yılmaz B, Yılmaz R, Demircioğlu İ, Arıcan İ. 2017. Morphological and histological structure of the interdigital gland in Awassi sheep (Ovis aries). Turkish Journal of Veterinary and Animal Sciences 41: 380-386. 